\title{
A Review of the Literature of the Relationship between Innovation and Internationalization of SMEs and Future Prospects
}

\author{
Guanhua Li \\ School of Management, Jinan University, Guangzhou, China \\ Email:lighheidi@163.com
}

How to cite this paper: Li, G. H. (2020). A Review of the Literature of the Relationship between Innovation and Internationalization of SMEs and Future Prospects. American Journal of Industrial and Business Management, 10, 619-636.

https://doi.org/10.4236/ajibm.2020.103041

Received: December 31, 2019

Accepted: March 14, 2020

Published: March 17, 2020

Copyright $\odot 2020$ by author(s) and Scientific Research Publishing Inc. This work is licensed under the Creative Commons Attribution International License (CC BY 4.0).

http://creativecommons.org/licenses/by/4.0/

\begin{abstract}
Innovation and internationalization are important strategic choices for SMEs. Previous studies have explored the relationship between them based on different theories. Innovation and internationalization have different mutual relationships in different regions and industries. In developed countries, innovation and internationalization are the "old topics" in academic research field. Whether internationalization has an impact on innovation remains questionable. In emerging markets, the relationship between innovation and internationalization presents different characteristics. The shortage of resources makes it hard to adopt both innovation and internationalization strategies. Combing the existing literature, this paper classifies the theoretical basis and research level of the literature, systematically analyzes the interaction of innovation and internationalization, and summarizes the existing research framework. Based on this, the future research directions in this field are pointed out.
\end{abstract}

\section{Keywords}

Innovation, Internationalization, Small and Medium Enterprises, Strategic Choice

\section{Introduction}

Innovation and internationalization are two enduring themes in enterprise research, as well as two important aspects of enterprise development. In an increasingly competitive modern society, the ability to innovate and internationalize is an essential competitiveness for enterprises (Harris \& $\mathrm{Li}, 2011$ ). On the global market, more than $80 \%$ of enterprises are SMEs (Gomez-Mejia et al., 2007), and 
there is a strong positive correlation between SMEs' exports and R\&D activities (Golovko \& Valentini, 2011). Many scholars have studied the relationship between innovation and internationalization. Interestingly, this is similar to the classic "chicken and egg" problem. Does innovation promote internationalization? Or does internationalization accelerate innovation? Through innovation, enterprises can improve their competitiveness in the international market, so as to expand the international market and improve their international performance (Cassiman \& Golovko, 2011). At the same time, the process of internationalization of enterprises provides opportunities for them to learn from exports.

Through "knowledge spillover" in the international market, enterprises realize how to improve products and services, thus stimulating their innovation motivation (Filippetti et al., 2017). Throughout the researches at home and abroad, there are more studies on the impact of innovation on internationalization, while fewer scholars have studied the impact of internationalization on innovation and the dynamic cycle relationship between innovation and internationalization (Kafouros et al., 2008). Some scholars have also questioned whether the relationship between internationalization and innovation really exists, or whether innovation and internationalization are just self-selection in the process of enterprise operation (Cassiman \& Martínez-Ros, 2007). Innovation and internationalization have different strategic choices in different markets. In emerging markets, due to the limited resources, experience and technological capabilities of enterprises, innovation and internationalization are not all mutually reinforcing relationships (Purkayastha et al., 2015), and may be a strategy of either (Cuervo-Cazurra \& Ramamurti, 2015). In developed countries, enterprises have accumulated a lot of resources in many years of business activities, "too much is as bad as too little" may also occur, and the specific relationship between innovation and internationalization is still worth exploring.

This article mainly discusses the interaction between innovation and internationalization of SMEs, summarizes the literature on the impact of innovation on internationalization, the impact of internationalization on innovation, and the relationship between the two under different theoretical perspectives and levels, and integrates existing research, proposes a model of the relationship between innovation and internationalization, and points out future research directions.

\section{Theoretical Perspective}

\subsection{Research Perspectives on Innovation and Internationalization Relations}

Innovation, including the creation and diffusion of products, processes and methods, is the key to creating new sources of growth and it provides the foundation for new industries, commerce and employment. Most current researches have explored changes in international performance from the perspectives of product innovation and process innovation (Kafouros et al., 2008). There is research evidence that SMEs with innovative experience are more inclined to ex- 
port products and can obtain more export growth (Altomonte et al., 2013). Internationalization is to some extent driven by innovation. The existing theoretical basis for the impact of innovation on internationalization includes the view of resource base, organizational learning theory, and policy system (Cuervo-Cazurra \& Ramamurti, 2015).

Resource-based view. The resource-based view holds that the unique resources or capabilities of an enterprise are the key to maintaining long-term competitiveness. Sapienza et al. (2006) believe that enterprises should adapt to the dynamic changes of the environment, constantly improve existing resources and capabilities in the changing environment, and maintain unique resource technologies. Innovation resources in enterprises play an important role. Olmos's research proves that product innovation in the wine industry is an important factor affecting the inter-nationalization of enterprises (Olmos, 2011). Mashahadi et al. (2016) demonstrate the relationship between technological dual innovation of SMEs and non-technological dual innovation and internationalization performance in the Malaysian herbal medicine industry, and find that only non-technical dual innovation could explain their internationalization performance. Maja et al. (2017) explain the relationship between product innovation capabilities, export scale, and export experience of emerging market countries from a resource-based perspective. The product innovation capability has a U-shaped relationship with export scale, and export experience has a negative moderating effect.

Organizational learning perspective. The purpose of an enterprise is to create value, and organizational learning ability is the embodiment of value creation and innovation ability, which can significantly affect innovation performance. Organizational learning positively affects enterprises' export performance, and it also has a positive effect on export performance through the mediating role of the extensiveness of technological innovation (Azar \& Ciabuschi, 2017). Mathews (2004) finds the "Four Asian Tigers" achieved internationalization by improving their autonomous learning capabilities. Similarly, autonomous learning can promote the internationalization of knowledge-intensive latecomers, and knowledge-intensive enterprises can improve their export performance through autonomous learning (Ray et al., 2017). From the perspective of spillover effects, the R\&D expenditure of health care in South Korea has a U-shaped relationship with internationalization, while the number of patents has an inverted U-shaped relationship with the degree of internationalization. In other words, after the internationalization degree reaches a moderate level, too many patents will cause the waste of capital and human resources and thus hinder the internationalization process (Nam \& An, 2017).

Absorptive capacity is an important concept in organizational learning. Absorptive capacity can promote strategic flexibility and innovation. Emerging market countries have weaker absorptive capacity. Bilgili et al. (2016) discover that they can choose the appropriate organizational learning strategy to promote 
innovation and internationalization according to their needs. The diversity of knowledge accumulation also plays an important role. Moreno and Casillas (2014) find that there is a U-shaped relationship between the diversity of enterprises' market and operation in the host country and the internationalization speed of enterprises, while there is an inverted u-shaped relationship between the depth of enterprises' market and operation in the host country and the internationalization speed of enterprises. Moreno and Casillas (2014) find that there is a U-shaped relationship between the diversity of the host country's market and operations and the speed of the company's internationalization. There is an inverted $U$-shaped relationship in the change rate.

Policies and systems. Regional policies play an important role in promoting regional innovation activities. For example, the governments of South Korea, Japan and Taiwan once introduced policies to encourage enterprises to learn and innovate independently. According to the survey of the World Bank, such policy orientation promoted enterprises' innovation ability and internationalization level.

In recent years, with the rapid economic growth of emerging markets, the relationship between innovation and internationalization in emerging markets has different characteristics from traditional studies. The government-invested strategic industries are all high value-added industries, and the huge capital investment and the sophisticated technology of high value-added businesses largely depend on the patent and R\&D expenditure demand of government departments. Cuervo-Cazurra and Ramamurti (2015) argue that innovation and internationalization in emerging markets has many new characteristics. Ramamurti (2016) discovers that emerging market companies often lack resources such as knowledge and technology, and have no advantage in product and technological innovation, which makes them inclined to innovate. The business model, selling products and services at lower prices to gain a competitive advantage abroad, has promoted their internationalization, that is, innovation-based internationalization (Cuervo-Cazurra \& Ramamurti, 2015). Due to institutional imperfections in emerging markets, some companies may pass on these costs to their customers, while others may use organizational innovation to solve institutional and organizational constraints, use innovative technologies for international expansion, and avoid weaknesses in the home country system. Li Xinchun and Xiao (2017) reveal that like formal institutions, informal institutions also drive SMEs in emerging economies to carry out OFDI, and innovation is the driving force under institutional constraints. From the perspective of social resources, enterprises in regions with backward systems are less constrained, which is more conducive to enterprises' R\&D internationalization and innovation activities ( $\mathrm{Li}$ \& Yu, 2016).

Due to the limited resources of enterprises in emerging markets, some scholars believe that enterprises are faced with a trade-off between expanding the international market and investing in innovative research and development when 
making investment decisions. In the pharmaceutical industry of India, Purkayastha et al. (2015) conclude through regression analysis that R\&D expenditure have a negative impact on export strength, and the relationship between internationalization of enterprise groups and diversification of enterprise groups is negatively adjusted (Purkayastha et al., 2015). Is there too much emphasis on the role of innovation in promoting internationalization in emerging markets? Too much emphasis on the positive effects of innovation? Further empirical analysis is needed.

Table 1 summarizes some theories that described how innovation affects internationalization. At the same time, we analyze several research levels, common variables and respective literatures to clarify current studies.

\subsection{Research Perspectives on Internationalization and Innovation Relations}

In the early 1990s, scholars found that business activities and corporate resources of enterprises can drive innovation, and the availability of foreign knowledge, knowledge spillovers, technological differences, and wage differences can stimulate innovation in export companies (Grossman \& Helpman, 1991). Exports can introduce better products and technologies, and at the same time bring resources to stimulate innovation for enterprises, enabling enterprises to obtain higher productivity than non-exporting enterprises, and play an important role in the process of innovation.

The impact of internationalization on innovation is controversial, and some scholars believe that the two interact with each other; some scholars believe that its essence is the impact of innovation on internationalization (Cassiman \& Martínez-Ros, 2007); another view is that internationalization and innovation are the self-selection of enterprises under its own operating conditions. Later, Bratti and Felice (2012) rigorously demonstrate that there is a statistically significant correlation between export activities and product innovations consistent with their export learning. This correlation persists even after controlling many observable firm characteristics, that is, exports can promote product innovation, and the two are causal (Bratti \& Felice, 2012). Generally speaking, internationalization affects innovation through three channels: imports, foreign direct investment and technology trade. Imports, foreign direct investment and technology transfer intensify competition, thereby increasing the incentive for innovation; exports provide enterprises with learning opportunities and incentives for innovation, that is, they provide decision-makers with valuable information to help new enterprises gain competitive advantages overseas (Braymen et al., 2011). Kafouros et al. (2008) provide a framework for analyzing how internationalization affects innovation, and discuss the impact of internationalization on innovation from the perspective of innovation capabilities and innovation possibilities. Most research focuses on the perspective of "learning by exporting", demonstrating that enterprises learn more technology and management knowledge 
Table 1. Theoretical framework, influencing factors of innovation-internationalization.

\begin{tabular}{|c|c|c|c|c|}
\hline Perspectives & levels & Independent variables & Dependent variables & literatures \\
\hline $\begin{array}{c}\text { Resource-based } \\
\text { view }\end{array}$ & Industry & $\begin{array}{l}\text { Non-technological } \\
\text { innovation } \\
\text { Product innovation }\end{array}$ & $\begin{array}{c}\text { Internationalization } \\
\text { performance } \\
\text { Degree of } \\
\text { internationalization }\end{array}$ & $\begin{array}{c}\text { Mashahadi et al. } \\
\text { (2016) } \\
\text { Olmos (2011) }\end{array}$ \\
\hline \multirow[t]{3}{*}{$\begin{array}{l}\text { Organization } \\
\text { learning }\end{array}$} & Company & Organization learning & $\begin{array}{c}\text { Speed of } \\
\text { internationalization }\end{array}$ & $\begin{array}{c}\text { Moreno and } \\
\text { Casillas (2014) }\end{array}$ \\
\hline & & $\begin{array}{c}\text { Resultant learning } \\
\text { Autonomous learning } \\
\text { Organizational } \\
\text { innovation }\end{array}$ & $\begin{array}{c}\text { Export } \\
\text { performance }\end{array}$ & $\begin{array}{l}\text { Ray et al. (2017) } \\
\text { Azar and } \\
\text { Ciabuschi (2017) }\end{array}$ \\
\hline & Industry & $\begin{array}{l}\text { R\&D expenditures } \\
\text { Patent numbers }\end{array}$ & $\begin{array}{c}\text { Export } \\
\text { performance }\end{array}$ & $\begin{array}{c}\text { Nam and An } \\
\text { (2017) }\end{array}$ \\
\hline \multirow[t]{2}{*}{ Micro view } & Nation & Product innovation & $\begin{array}{c}\text { Internationalization } \\
\text { performance }\end{array}$ & $\begin{array}{c}\text { Castano et al. } \\
\text { (2016) }\end{array}$ \\
\hline & Nation & Innovation & Internationalization & $\begin{array}{l}\text { Altomonte et al. } \\
\text { (2013) }\end{array}$ \\
\hline $\begin{array}{l}\text { Dynamic } \\
\text { capacities }\end{array}$ & Industry & $\begin{array}{c}\text { Non-technological } \\
\text { innovation }\end{array}$ & $\begin{array}{c}\text { Internationalization } \\
\text { performance }\end{array}$ & $\begin{array}{c}\text { Mashahadi et al. } \\
\text { (2016) }\end{array}$ \\
\hline
\end{tabular}

through internationalization to promote their own innovation.

Spillover effect. Knowledge diffusion is a common phenomenon in internationalization activities, that is, knowledge spillover, which enables enterprises to learn advanced technology and management methods. During internationalization, enterprises can have access to knowledge and technologies different from domestic markets. In the early days, international trade is regarded as the main channel for technology diffusion. Keller (2002) find compared with underdeveloped countries, the spillover effect of OFDI in developed countries is stronger. Later researchers find that patent citations are a manifestation of the transfer of knowledge through international trade and direct investment (Breschi et al., 2005). Bertschek (1995) uses German manufacturing data to prove that both imports volume and foreign investment have a positive and significant impact on product and process innovation. Empirical studies have shown that exports and innovation are positively correlated (Castellani \& Zanfei, 2007). Gorodnichenko et al. (2010) obtain a positive correlation between internationalization and innovation from data of emerging markets. Internationalization activities also vary from industry to industry, and for the service sector, there is no significant relationship between exports and innovation (Braymen et al., 2011). Only when an enterprise has the ability to absorb learning can it be transformed into its own competitive advantage. Whether an enterprise can internalize spillover knowledge into its own capabilities depends on the diffusion channel and the enterprise's absorptive capacity. Filippetti et al. (2017) study the role of absorptive capacity between internationalization and innovation, and find that in countries with low absorptive capacity, there is a negative correlation between foreign direct investment and patent applications, and in countries with high 
absorptive capacity, and there is a positive correlation between foreign direct investment and patent applications. Liu and Buck (2007) study the impact of three main channels of international spillover effect-the $R \& D$ activities of foreign multinational corporations, export sales, and imported technology expenditures-on product innovation. In the process of product innovation, the interaction between absorptive capacity and three internationalization models plays a positive and significant role. Piperopoulos et al (2018) argue that from the perspective of organizational learning, enterprises in developed economies usually rely on internal research and accumulate experience learning to develop technological advantages. Emerging economies have path dependence, strong government participation and underdeveloped institutions, which make it difficult for emerging market economies to adopt this learning model, and foreign investment and export may be more suitable for emerging markets.

Other perspectives. Internationalization strategies and international entrepreneurship theories explain in detail the factors that promote corporate growth (Golovko \& Valentini, 2011). Ren et al. (2015) use the data of Chinese SMEs to study the role of internationalization level, research and development capabilities, and market capabilities on the innovation performance of enterprises. The results prove that the degree of internationalization has a positive impact on the research and development capabilities or marketing capabilities of SMEs. When the ability or marketing ability is low, the impact of internationalization on innovation performance is negative, and the research and development ability or marketing ability is a completely intermediary role, which can strengthen the role of internationalization on innovation. Li et al. (2016) study the positive correlation between OFDI and regional innovation from the perspective of international business theory and regional innovation system theory. The relationship between regional absorptive capacity and competition intensity is positively and negatively regulated, respectively. Social resources also play an important role between the internationalization of R\&D and innovation, and the degree of role varies according to the level of institutions in the region ( $\mathrm{Li} \& \mathrm{Yu}, 2016$ ). With the development of the concept of sustainable development, green innovation has become a hot topic in recent years. The export tendency of Italian mid-tech and low-tech companies in the downstream internationalization is negatively related to environmental innovation (Chiarvesio et al., 2015).

Table 2 combines studies on relationships of internationalization and innovation. We divide them into two types according to theoretical perspectives. The details are as follows.

\section{Research Level}

\subsection{Research Levels on Innovation and Internationalization Relations}

We divide the research level of innovation and internationalization into national level, industry level and enterprise level. 
Table 2. Theoretical framework, influencing factors of internationalization-innovation.

\begin{tabular}{|c|c|c|c|c|}
\hline Perspectives & levels & Independent variables & Dependent variables & literatures \\
\hline \multirow[t]{2}{*}{ Spillover effect } & Nation & Internationalization & Innovation & $\begin{array}{l}\text { Filippetti et al. } \\
\text { (2017) }\end{array}$ \\
\hline & Company & OFDI & $\begin{array}{l}\text { Innovation } \\
\text { performance }\end{array}$ & $\begin{array}{c}\text { Piperopoulos et al. } \\
\text { (2018) }\end{array}$ \\
\hline $\begin{array}{l}\text { International new } \\
\text { venture and } \\
\text { marketing theory }\end{array}$ & Company & $\begin{array}{c}\text { Internationalization } \\
\text { level }\end{array}$ & $\begin{array}{l}\text { Innovation } \\
\text { performance }\end{array}$ & Ren et al. (2015) \\
\hline $\begin{array}{l}\text { Sustainability } \\
\text { perspective }\end{array}$ & Industry & $\begin{array}{l}\text { Upstream and } \\
\text { downstream } \\
\text { internationalization } \\
\text { export propensity }\end{array}$ & $\begin{array}{c}\text { Environmental } \\
\text { innovation }\end{array}$ & $\begin{array}{l}\text { Chiarvesio et al. } \\
\qquad(2015)\end{array}$ \\
\hline $\begin{array}{l}\text { International } \\
\text { business theory }\end{array}$ & Province & IFDI & $\begin{array}{l}\text { Regional innovation } \\
\text { performance }\end{array}$ & Li et al. (2016) \\
\hline Social resource & Company & $\begin{array}{c}\text { R \& D } \\
\text { internationalization }\end{array}$ & $\begin{array}{l}\text { Innovation } \\
\text { performance }\end{array}$ & $\begin{array}{l}\text { Li Mei and Yu } \\
\text { Tianjiao (2016) }\end{array}$ \\
\hline
\end{tabular}

The country. At the macro level, there are few studies on the relationship between the overall level of innovation and the level of internationalization (Chang et al., 2011). Castano et al. (2016) analyze the service industry data in 17 countries and find that product innovation positively affects the internationalization performance of service industry start-ups. Altomonte et al. (2013) study the manufacturing enterprise data in developed countries and find that the innovation intensity and internationalization intensity are positively correlated at the national level. In empirical studies of developing countries, the product innovation capability and export scope have a U-shaped relationship.

The industry. Nam and An (2017) find an inverted U-shaped relationship between R\&D expenditure, patents and export performance in the Korean health care industry. When the level of internationalization is not high, innovation can promote internationalization, while too many patents will lead to the redundancy of resource utilization and hinder international development. The Chinese-African technology dual innovation in Malaysia's Chinese herbal medicine industry explains the level of internationalization of enterprises. The technological innovation in this industry has not yet been perfected and is not reflected in international performance (Mashahadi et al., 2016). Product innovation in the wine industry plays an important role. Compared with process innovation, product innovation can improve international performance (Olmos, 2011). From the perspective of organizational learning, the autonomous learning ability of knowledge-intensive industries is positively affecting its international knowledge accumulation (Ray et al., 2017).

The enterprise. Most research on the topic of the impact of innovation on internationalization is empirical research on enterprise-level data (Damijan et al., 2008). Azar and Ciabuschi (2017) study Swedish export trading companies and find that organizational innovation not only directly affects the export perfor- 
mance of enterprises, but also positively affects export performance through influencing the extensiveness of technological innovation (Azar \& Ciabuschi, 2017). Cassiman and Golovko (2011) believe that product innovation improves productivity and promotes enterprises to enter export markets (Cassiman \& Golovko, 2011). The breadth and depth of internationalization knowledge that companies have has a significant impact on its internationalization speed: the diversity of markets and business models will reduce the business expansion speed in the short term, but will accelerate it in the long term; the depth of international activities will accelerate the growth rate of international business in the short term and will slow down it in the long term (Moreno \& Casillas, 2014).

Table 3 describes the study level of the affect of innovation on internationalization. Among the representative literatures, most of the researches work on

Table 3. Summary of innovation-internationalization research.

\begin{tabular}{|c|c|c|c|c|}
\hline $\begin{array}{l}\text { Research } \\
\text { levels }\end{array}$ & Theme & Dimensions & $\begin{array}{l}\text { Influential } \\
\text { impact }\end{array}$ & literatures \\
\hline \multirow[t]{14}{*}{ Company } & $\begin{array}{l}\text { Organization } \\
\text { learning }\end{array}$ & $\begin{array}{l}\text { Diversity of experience } \\
\text { Depth of accumulated } \\
\text { operating experience }\end{array}$ & + & $\begin{array}{c}\text { Moreno and } \\
\text { Casillas (2014) }\end{array}$ \\
\hline & Resultant learning & & & \\
\hline & Autonomous learning & & & Ray et al. (2017) \\
\hline & Organizational & learn(LLL) & + & Azar and Ciabu- \\
\hline & innovation & Management innoyation & + & schi (2017) \\
\hline & Technological & Marketing innovation & & Cassiman and \\
\hline & innovation & & + & Golovko (2011) \\
\hline & Product innovation & & & \\
\hline & Innovation & $\begin{array}{c}\text { Innovation intensity } \\
\text { /output/input }\end{array}$ & + & $\begin{array}{l}\text { Altomonte et al. } \\
\qquad(2013)\end{array}$ \\
\hline & & Diversity of investment & $-($ short term $)$ & \\
\hline & Fxperience learning & countries & $+($ long term $)$ & Moreno, Castell, \\
\hline & вxpertence tedming & Operating experience in & $+($ short term $)$ & \& Ramirez (2017) \\
\hline & & investing countries & - (long term) & \\
\hline & Innovation & $\begin{array}{l}\text { Product/process/ } \\
\text { marketing innovation }\end{array}$ & + & $\begin{array}{l}\text { Lewandowska } \\
\text { et al. (2016) }\end{array}$ \\
\hline \multirow{5}{*}{ Industry } & & $\begin{array}{c}\text { Technological innovation } \\
\text { ambidexterity }\end{array}$ & not significant & Mashahadi et al. \\
\hline & Dual innovation & $\begin{array}{c}\text { Non-technological } \\
\text { innovation ambidexterity }\end{array}$ & + & (2016) \\
\hline & Patent P \& D & $\mathrm{R} \& \mathrm{D}$ expenditure & U-shape & Nam and An \\
\hline & Paten K $\alpha \mathrm{D}$ & Patent Number & Inverted U-shape & (2017) \\
\hline & Innovation & $\begin{array}{l}\text { Product innovation } \\
\text { Process innovation }\end{array}$ & $\begin{array}{c}+ \\
\text { not significant }\end{array}$ & Olmos (2011) \\
\hline \multirow[t]{2}{*}{ Nation } & Product innovation & Limited competition & + & $\begin{array}{l}\text { Castano et al. } \\
\qquad(2016)\end{array}$ \\
\hline & & Customer recognition & + & \\
\hline Mix-level & Innovation & $\begin{array}{l}\text { Innovation intensity/ } \\
\text { output/investment }\end{array}$ & + & $\begin{array}{l}\text { Altomonte et al. } \\
\qquad(2013)\end{array}$ \\
\hline
\end{tabular}


company level, while few studies analyze this theme on nation level or mix-level.

\subsection{Research Levels on Internationalization and Innovation Relations}

Internationalization-innovative research exists at both the micro and macro levels. In the early years, relevant literature on economics focused on the macro level, while in recent years, research on the micro level has been the main focus.

The country. Filippetti et al. (2017) study the internationalization level (foreign and domestic direct investment, import and export level) and innovation (tripartite patent application) of 40 countries and regions, and find that absorption capacity positively regulates the positive correlation between OFDI and innovation. This verifies the "learning by exporting" proposed by scholars. Therefore, countries with high absorptive capacity can benefit from foreign investment activities, while countries with low absorptive capacity can learn from export and import activities, but cannot benefit from foreign investment activities. As mentioned earlier, innovation and internationalization in emerging markets differ from those in developed world. Li et al. (2016) explore the impact of FDI on regional innovation performance in the context of China. Using provinces as research units, they find that there is a complementary relationship between foreign direct investment and regional innovation (Li et al., 2016).

Industry and company. At the industry level, Chiarvesio et al. (2015) find that the higher the internationalization of Italy's mid and low-end technology industry, the lower its tendency to invest in green innovation (Chiarvesio et al., 2015), while absorption capacity and internationalization mode play a positive and significant role (Liu \& Buck, 2007).

At the company level, the ultimate source of innovation is also the main channel of export activities, through which export activities can promote the introduction of new and better products. Salomon and Shaver (2005) study the Spanish manufacturing sector and find that its export status and volume have a positive impact on innovation performance, with $R \& D$ spending moderating the process. Ren (2015) uses international entrepreneurship and market theory to explain the factors influencing innovation performance of Chinese SMEs. In the case of high R\&D capacity, internationalization has a positive impact on innovation performance, while in the case of low R\&D capacity, internationalization has a negative impact on innovation performance (Ren et al., 2015). This also shows that innovation and internationalization in emerging markets are not absolutely positively correlated. In emerging markets, China's high-tech industry can gain knowledge and capability from outbound investment activities, and OFDI has a positive impact on the company's innovation performance, which is stronger when investing in developed countries (Piperopoulos et al., 2018).

Table 4 summarizes studies on how internationalization effected innovation. Many scholars claim internationalization positively affected innovation, while others emphasize their relationship is not always positive when company or nation has low absorb or marketing abilities. 
Table 4. Summary of internationalization-innovation research.

\begin{tabular}{|c|c|c|c|c|}
\hline $\begin{array}{c}\text { Research } \\
\text { levels }\end{array}$ & Theme & Dimensions & Influential impact & literatures \\
\hline Company & Internationalization & Export ratio & $\begin{array}{c}+ \text { (High R \& D and } \\
\text { marketing capabilities }) \\
-(\text { Low R \& D and } \\
\text { marketing capabilities })\end{array}$ & Ren et al. (2015) \\
\hline Industry & Internationalization & $\begin{array}{c}\text { Export }^{\mathrm{a}} \\
\text { Foreign company }^{\mathrm{b}} \\
\text { FDI }\end{array}$ & $\begin{array}{l}+ \\
+ \\
+\end{array}$ & $\begin{array}{c}\text { Chiarvesio et al. } \\
\text { (2015) }\end{array}$ \\
\hline \multirow[t]{2}{*}{ Nation } & Internationalization & OFDI\IFDI & - (Low absorb capacity) & $\begin{array}{l}\text { Filippetti et al. } \\
\text { (2017) }\end{array}$ \\
\hline & Absorb Capacity & Three indicates ${ }^{c}$ & + & \\
\hline
\end{tabular}

a. Knowledge background, basic organizational structure supporting the connection, human resources infrastructure; b. Companies that export more than half of their turnover; c. Companies affiliated with foreign groups.

\section{The Interaction between Internationalization and Innovation}

According to Funk (2001), the relationship between innovation and internationalization can be divided into three types: First, after the enterprises pursuing innovation have sufficient competitiveness in the international market, an internationalization strategy emerges as the times require; Second, internationalization strategy urges enterprises to make innovation investment; Third, international enterprises learn from their contacts with customers and competitors to promote corporate innovation.

Golovko and Valentini (2011) believe that innovation and export are complementary strategies for SMEs, and the two are mutually reinforcing dynamic circular relations. Export is an advantageous way for enterprises to quickly learn external knowledge, thereby promoting innovation. At the same time, through innovative enterprises to produce higher quality and novel products, expand overseas markets and improve export performance. Therefore, the causal relationship between innovation and internationalization is a two-way process. Filippetti et al. (2011) prove the two-way circular relationship between innovation and internationalization through empirical cross-level analysis. From a micro perspective, it is easier for innovative enterprises to promote their products to foreign markets and achieve internationalization. Multinational companies can have access to more cultural environment and innovation resources, so as to improve their innovation ability, which is more conducive to improving international performance. This two-way process is also applicable at the macro level.

Some studies suggest that the limited nature of organizational resources (human capital, material resources) makes internationalization and innovation the only growth strategy of choice. Roper and Love (2002) argue that German enterprises are faced with a trade-off between enhanced innovation and international expansion: focusing on product $\mathrm{R} \& \mathrm{D}$ in the domestic market or invest less in R\&D to expand foreign markets. Similarly, Kumar (2009) finds a negative 
correlation between short-term product diversity and internationalization diversity. As mentioned above, many scholars believe that the impact of internationalization on innovation is rooted in the impact of innovation on internationalization, and the consistent view is that innovation and internationalization only promote the growth of enterprises. Therefore, the interaction between innovation and internationalization deserves further discussion, especially in the context of emerging markets.

Based on the above points, we summarize the model of innovation-internationalization in Figure 1. The main variables are divided into different dimensions.

Most researches focus on the influence of moderating variables. The measurement dimensions of innovation include the number of patents, R\&D expenditure, autonomous learning ability and experience learning, etc., which are divided into organizational innovation, non-technical embedded innovation and product innovation. The description of internationalization mainly focuses on export performance, internationalization expansion speed, export intensity, etc., and focuses on export-related factors.

Figure 2 shows the main variables which described how internationalization impacted innovation. Moderator is often used to explain their relationship. The model is summarized as follows:

Internationalization as an independent variable is measured by investment and import and export, such as FDI, IDI, export intensity, total import and export, and internationalization level. There are many kinds of innovation in terms of dimensions, and the measurement is generally based on the number of patents. The scope of the moderator variables is relatively diverse, including environmental factors such as the intensity of competition, and corporate factors such as absorption capacity, market capacity and investment location selection. There are many relationships between internationalization and innovation.

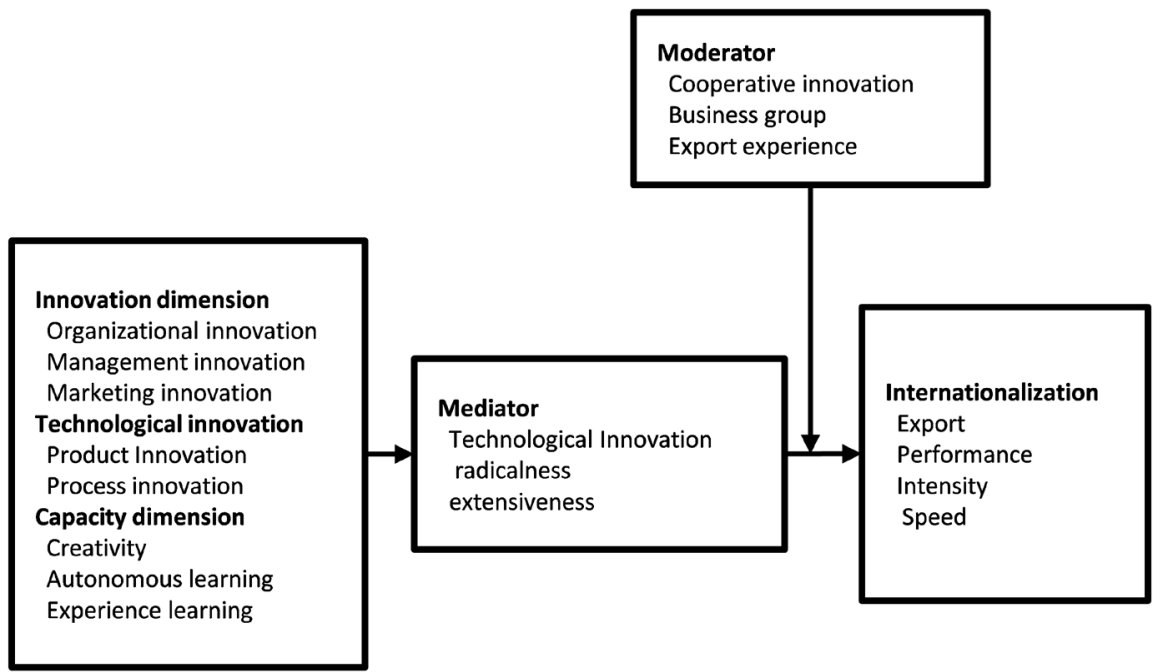

Figure 1. Model of innovation-internationalization. 


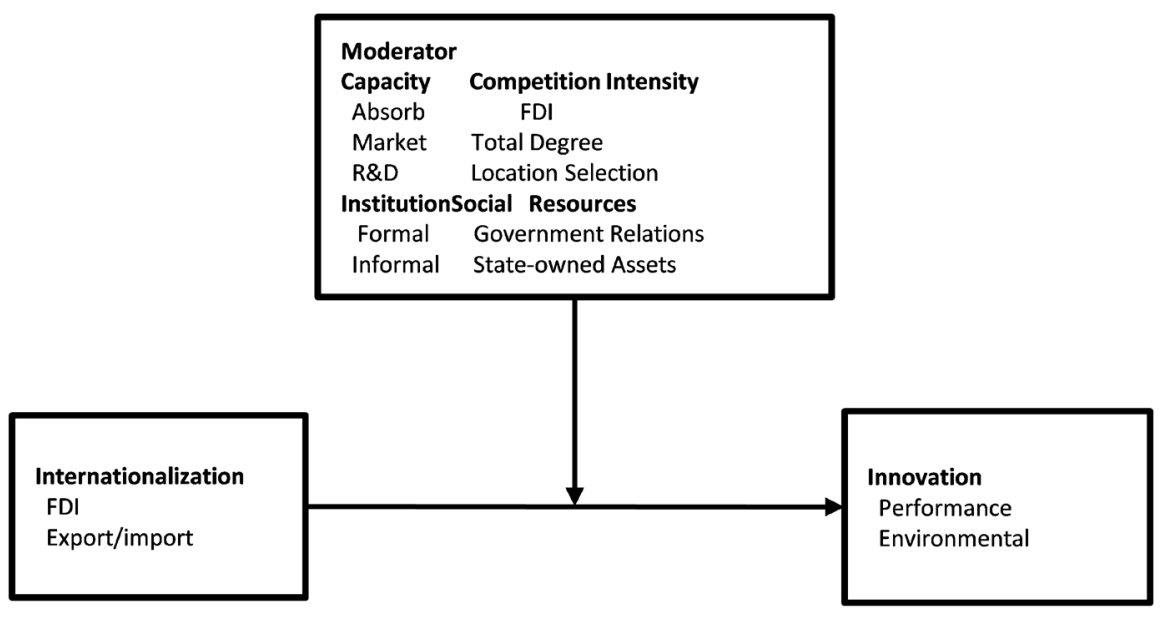

Figure 2. Model of internationalization-innovation.

Taking R\&D internationalization as an example, Wang Zhanshuo and Xie Wei (2018) find the relationship between linearity, U-shape, and S-shape varies depending on factors such as the investment environment and the development stage of an enterprise.

\section{Future Research}

In the field of innovation-internationalization, the relationship between innovation and internationalization deserves further consideration by scholars. The specific situation of developing countries can be considered, and research on internationalization strategies can be studied. Changes in strategy formulation, innovation and dynamic aspects of internationalization are also worthy of attention (Azar \& Ciabuschi, 2017). Pan Qiuyue et al. (2013) appeal subsequent researches to consider the R\&D situation of enterprises from the boundary of geography, organization and knowledge, and comprehensively analyze their internationalization process.

In the field of internationalization-innovation, further empirical analysis is needed. As mentioned before, some scholars believe that its essence is the impact of innovation on internationalization (Cassiman \& Martínez-Ros, 2007). However, there is little empirical support for the impact of internationalization strategy on innovation. Future research may focus on the diffusion and absorption of knowledge: whether the network of foreign subsidiaries in emerging markets spreads advanced knowledge, $R \& D$ and innovation capabilities to headquarters and other departments around the world, thereby improving the innovation performance of the entire emerging market; how companies obtain experience and knowledge through overseas investment (Piperopoulos et al., 2018). Oura et al. (2016) suggest the role of variables related to the institutional environment in this process can also be considered. In addition, the impact of technological progress and export market characteristics on innovation remains to be studied. (Lewandowska et al., 2016). Other aspects of internationalization may also affect 
innovation, especially when SMEs in emerging markets enter the international market as a latecomer, their internationalization regions, method selection and so on are worth paying attention to (Ren et al., 2015).

The inter-relationship between innovation and internationalization is closely related to regions and industries. Bonaglia et al. (2007) believe that internationalization of white electricity industry involves strategic innovation, but does not include technological innovation of product and process innovation. However, in knowledge-intensive industries, knowledge creation and technological invention will allow the latecomers to occupy the dominant position in the international market (Ray et al., 2017), while the situation in other industries needs to be further discovered. Regarding the interaction between internationalization and innovation, scholars have different opinions and empirical findings. On the one hand, from the perspective of organizational learning and absorptive capacity, internationalization and innovation promote each other. On the other hand, from the perspective of limited resources, corporate strategic decisions and capital investment are not allowed to have both (Purkayastha et al., 2015). Especially in the context of emerging markets, most studies have proved the negative correlation between innovation and internationalization. Future research can focus on the strategic choices of enterprises: under what circumstances enterprises can only choose one between internationalization and innovation, and under what circumstances enterprises can take both into consideration and develop together.

As emerging economies gradually integrate into the global market, there are few researches on innovation and internationalization in the context of emerging markets (Purkayastha et al., 2015). How can enterprises from emerging markets achieve internationalization? How is it different from the internationalization process of companies in developed countries? How does innovation and internationalization develop under conditions of imperfect institutions? These topics are worthy of further discussion (Ray et al., 2017).

\section{Conclusion}

Innovation and internationalization are very important strategies for company development and competence. According to literature study, we discover innovation and internationalization research mainly based on resource-based view, organization learning, spillover effect and other theories. Company analysis is the most popular study level as well as industry and nation. Different nations and industries show different conditions, but most studies give positive inter-relationship between innovation and internationalization. They do not coexist; on the contrary, they can mutually promote each other.

\section{Acknowledgements}

Thanks to my teachers and classmates for their help, this article was successfully published. Thanks to Jinan University for giving me many opportunities and 
challenges, I will continue to work hard.

\section{Conflicts of Interest}

The author declares no conflicts of interest regarding the publication of this paper.

\section{References}

Altomonte, C., Aquilante, T., Bekes, G., Ottaviano, G. I. P., \& Manacorda, M. (2013). Internationalization and Innovation of Firms: Evidence and Policy. Economic Policy, 28, 663-700. https://doi.org/10.1111/1468-0327.12020

Azar, G., \& Ciabuschi, F. (2017). Organizational Innovation, Technological Innovation, and Export Performance: The Effects of Innovation Radicalness and Extensiveness. International Business Review, 26, 324-336. https://doi.org/10.1016/j.ibusrev.2016.09.002

Bertschek, I. (1995). Product and Process Innovation as a Response to Increasing Import and Foreign Direct Investment. The Journal of Industrial Economics, 43, 341-357. https://doi.org/10.2307/2950548

Bilgili, T. V., Kedia, B. L., \& Bilgili, H. (2016). Exploring the Influence of Resource Environments on Absorptive Capacity Development: The Case of Emerging Market Firms. Journal of World Business, 51, 700-712. https://doi.org/10.1016/j.jwb.2016.07.008

Bonaglia, F., Goldstein, A., \& Mathews, J. A. (2007). Accelerated Internationalization by Emerging Markets' Multinationals: The Case of the White Goods Sector. Journal of World Business, 42, 369-383. https://doi.org/10.1016/j.jwb.2007.06.001

Bratti, M., \& Felice, G. (2012). Are Exporters More Likely to Introduce Product Innovations? World Economy, 35, 1559-1598. https://doi.org/10.1111/j.1467-9701.2012.01453.x

Braymen, C., Briggs, K., \& Boulware, J. (2011). R\&D and the Export Decision of New Firms. Southern Economic Journal, 78, 191-210. https://doi.org/10.4284/0038-4038-78.1.191

Breschi, S., Lissoni, F., \& Montobbio, F. (2005). The Geography of Knowledge Spillovers: Conceptual Issues and Measurement Problems. Clusters, Networks and Innovation, 22, 343-367.

Cassiman, B., \& Golovko, E. (2011). Innovation and Internationalization through Exports. Journal of International Business Studies, 42, 56-75. https://doi.org/10.1057/jibs.2010.36

Cassiman, B., \& Martínez-Ros, E. (2007). Product Innovation and Exports. IESE Working Paper.

Castano, M. S., Mendez, M. T., \& Galindo, M. A. (2016). Innovation, Internationalization and Business-Growth Expectations among Entrepreneurs in the Services Sector. Journal of Business Research, 69, 1690-1695. https://doi.org/10.1016/j.jbusres.2015.10.039

Castellani, D., \& Zanfei, A. (2007). Internationalization, Innovation and Productivity: How Do Firms Differ in Italy? The World Economy, 30, 156-176. https://doi.org/10.1111/j.1467-9701.2007.00875.x

Chang, C. L., Chen, S. P., \& Mcaleer, M. (2011). Globalization and Knowledge Spillover: International Direct Investment, Exports and Patents. In Proceedings of International Congress on Modelling and Simulation (pp. 57-69). Perth: Modelling \& Simulation SOC Australia \& New Zealand.

Chiarvesio, M., De Marchi, V., \& Di Maria E. (2015). Environmental Innovations and In- 
ternationalization: Theory and Practices. Business Strategy and the Environment, 24, 790-801. https://doi.org/10.1002/bse.1846

Cuervo-Cazurra, A., \& Ramamurti, R. (2015). Home Country Underdevelopment and Internationalization Innovation-Based and Escape-Based Internationalization. Competitiveness Review: An International Business Journal, 27, 1-26.

Damijan, J. P., Crt, K., \& Matija, R. (2008). Innovation and Firms' Productivity Growth in Slovenia-Sensitivity of Results to Sectoral Heterogeneity and to Estimation Method. SSRN Electronic Journal, 1, 165-193. https://doi.org/10.2139/ssrn.1131155

Filippetti, A., Frenz, M., \& Ietto-Gillies, G. (2011). Are Innovation and Internationalization Related? An Analysis of European Countries. Industry and Innovation, 18, 437-459. https://doi.org/10.1080/13662716.2011.583461

Filippetti, A., Frenz, M., \& Ietto-Gillies, G. (2017). The Impact of Internationalization on Innovation at Countries' Level: the Role of Absorptive Capacity. Cambridge Journal of Economics, 41, 413-439. https://doi.org/10.1093/cje/bew032

Funk, M. (2001). Trade and International R\& D Spillovers among OECD Countries. Southern Economic Journal, 67, 725-736. https://doi.org/10.2307/1061461

Golovko, E., \& Valentini, G. (2011). Exploring the Complementarity between Innovation and Export for SMEs' Growth. Journal of International Business Studies, 42, 362-380. https://doi.org/10.1057/jibs.2011.2

Gomez-Mejia, L., Haynes, K., Núñez-Nickel, M., Jacobson, K. J. L., \& Moyano-Fuentes, J. (2007). Socioemotional Wealth and Business Risks in Family-Controlled Firms: Evidence from Spanish Olive Oil Mills. Administrative Science Quarterly, 52, 106-137. https://doi.org/10.2189/asqu.52.1.106

Gorodnichenko, Y., Svejnar, J., \& Terrell, K. (2010). Globalization and Innovation in Emerging Markets. American Economic Journal, 2, 194-226.

https://doi.org/10.1257/mac.2.2.194

Grossman, G. M., \& Helpman, E. (1991). Innovation and Growth in the Global Economy. Cambridge, MA: MIT Press.

Harris, R., \& Li, Q. C. (2011). Participation in Export Markets and the Role of R\&D: Establishment-Level Evidence from the UK Community Innovation Survey. Applied Economics, 43, 3007-3020. https://doi.org/10.1080/00036840903427190

Kafouros, M. I., Buckley, P. J., Sharp, J. A., \& Wang, C. Q. (2008). The Role of Internationalization in Explaining Innovation Performance. Technovation, 28, 63-74. https://doi.org/10.1016/j.technovation.2007.07.009

Keller, W. (2002). Geographic Localization of International Technology Diffusion. American Economic Review, 92, 120-142. https://doi.org/10.1257/000282802760015630

Kumar, M. V. S. (2009). The Relationship between Product and International Diversification: The Effects of Short-Run Constraints and Endogeneity. Strategic Management Journal, 30, 99-116. https://doi.org/10.1002/smj.724

Lewandowska, M. S., Szymura-Tyc, M., \& Gołębiowski, T. (2016). Innovation Complementarity, Cooperation Partners, and New Product Export: Evidence from Poland. Journal of Business Research, 69, 3673-3681. https://doi.org/10.1016/j.jbusres.2016.03.028

Li, J., Strange, R., Ning, L. T., \& Sutherland, D. (2016). Outward Foreign Direct Investment and Domestic Innovation Performance: Evidence from China. International Business Review, 25, 1010-1019. https://doi.org/10.1016/j.ibusrev.2016.01.008

Li, M., \& Yu, T. J. (2016). Does R\&D Internationalization Promote Enterprise Innovation: 
An Empirical Study Based on Chinese Information Technology Enterprises. Management World, 11, 125-140.

Li, X. C., \& Xiao, X. (2017). Institutional Escapism or Innovation-Driven? Institutional Constraints and Chinese Private Enterprises' Outward Foreign Direct Investment. Management World, 10, 99-112.

Liu, X., \& Buck, T. (2007). Innovation Performance and Channels for International Technology Spillovers: Evidence from Chinese High-Tech Industries. Research Policy, 36, 355-366. https://doi.org/10.1016/j.respol.2006.12.003

Maja, A. K., Bernardo, B., Selma, K. M., Guido, B., Svensson, G., \& Dabic, M. (2017). Product Innovation Capability, Export Scope and Export Experience: Quadratic and Moderating Effects in Firms from Developing Countries. European Business Review, 29, 680-696. https://doi.org/10.1108/ebr-12-2015-0180

Mashahadi, F., Ahmad, N. H., \& Mohamad, O. (2016). Strategic Innovation Ambidexterity and the Internationalization Performance of Small and Medium Enterprises an Insight into Herbal-Based Small and Medium Enterprises (HbSMEs). World Journal of Entrepreneurship Management and Sustainable Development, 12, 161-175. https://doi.org/10.1108/WJEMSD-09-2015-0036

Mathews, J. A. (2004). Competitiveness, FDI and Technological Activity in East Asia. Research Policy, 33, 1060-1062. https://doi.org/10.1016/j.respol.2004.04.002

Moreno, S., Castell, O., \& Ramirez, A. (2017). Services Sector in Colombia: Relationship between Innovation and Internationalization. Dimension Empresarial, 15, 117-139. https://doi.org/10.15665/rde.v15i2.927

Moreno-Menendez, M., \& Casillas, J. C. (2014). Speed of the Internationalization Process: The Role of Diversity and Depth in Experiential Learning. Journal of International Business Studies, 45, 85-101. https://doi.org/10.1057/jibs.2013.29

Nam, H., \& An, Y. (2017). Patent, R\&D and Internationalization for Korean Healthcare Industry. Technological Forecasting and Social Change, 117, 131-137. https://doi.org/10.1016/j.techfore.2016.12.008

Olmos, M. F. (2011). The Determinants of Internationalization: Evidence from the Wine Industry. Applied Economic Perspectives and Policy, 33, 384-401. https://doi.org/10.1093/aepp/ppr017

Oura, M. M., Zilber, S. N., \& Lopes, E. L. (2016). Innovation Capacity, International Experience and Export Performance of SMEs in Brazil. International Business Review, 25, 921-932. https://doi.org/10.1016/j.ibusrev.2015.12.002

Pan, Q. Y., Wei, J., \& Liu, Y. (2013). A Review of the Literature of Internationalization of R\&D Network and Future Prospects. Foreign Economics \& Management, 35, 27-35. https://doi.org/10.1080/02783193.2013.740600

Piperopoulos, P., Wu, J., \& Wang, C. (2018). Outward FDI, Location Choices and Innovation Performance of Emerging Market Enterprises. Research Policy, 47, 232-240. https://doi.org/10.1016/j.respol.2017.11.001

Purkayastha, S., Manolova, T. S., \& Edelman, L. F. (2015). Business Group Effects on the Innovation-Internationalization Relationship: Evidence from the Indian Pharmaceutical Sector. In Proceedings of the Emerging Economies and Multinational Enterprises (pp. 379-402). Boston, MA: Emerald Group Publishing Ltd. https://doi.org/10.1108/S1571-502720150000028017

Ramamurti, R. (2016). Internationalization and Innovation in Emerging Markets. Strategic Management Journal, 37, 74-83. https://doi.org/10.1002/smj.2553

Ray, P. K., Ray, S., \& Kumar, V. (2017). Internationalization of Latecomer Firms from 
Emerging Economies: The Role of Resultant and Autonomous Learning. Asia Pacific Journal of Management, 34, 851-873. https://doi.org/10.1007/s10490-017-9527-y

Ren, S. C., Eisingerich, A. B., \& Tsai, H. T. (2015). How Do Marketing, Research and Development Capabilities, and Degree of Internationalization Synergistically Affect the Innovation Performance of Small and Medium-Sized Enterprises (SMEs)? A Panel Data Study of Chinese SMEs. International Business Review, 24, 642-651. https://doi.org/10.1016/j.ibusrev.2014.11.006

Roper, S., \& Love, J. (2002). Innovation and Export Performance: Evidence from the UK and German Manufacturing Plants. Research Policy, 31, 1087-1102. https://doi.org/10.1016/S0048-7333(01)00175-5

Salomon, R. M., \& Shaver, J. M. (2005). Learning by Exporting: New Insights from Examining Firm Innovation. Journal of Economics \& Management Strategy, 14, 431-460. https://doi.org/10.1111/j.1530-9134.2005.00047.x

Sapienza, H. J., Autio, E., George, G., \& Zahra, S. A. (2006). A Capabilities Perspective on the Effects of Early Internationalization on Firm Survival and Growth. Academy of Management Review, 31, 914-933. https://doi.org/10.5465/amr.2006.22527465

Wang, Z. S., \& Xie, W. (2018). An Analysis on the Procedure and Consequences of R\&D Internationalization to Enterprise Innovation Performance. Foreign Economics \& Management, 40, 55-70. 